\title{
Functional Compensation of $\mathrm{P} / \mathrm{Q}$ by N-Type Channels Blocks Short-Term Plasticity at the Calyx of Held Presynaptic Terminal
}

\author{
Carlota González Inchauspe, ${ }^{1}$ Francisco J. Martini, ${ }^{1}$ Ian D. Forsythe, ${ }^{2}$ and Osvaldo D. Uchitel ${ }^{1}$ \\ ${ }^{1}$ Instituto de Fisiología, Biología Molecular y Neurociencias, Consejo Nacional de Investigaciones Científicas y Técnicas, Departamento de Fisiología, \\ Biología Molecular y Celular, Facultad de Ciencias Exactas y Naturales, Universidad de Buenos Aires, Buenos Aires 1428, Argentina, and ${ }^{2}$ Department of \\ Cell Physiology and Pharmacology, University of Leicester, Leicester LE1 9HN, United Kingdom
}

\begin{abstract}
Calcium channels of the $\mathrm{P} / \mathrm{Q}$ subtype mediate transmitter release at the neuromuscular junction and at many central synapses, such as the calyx of Held. Transgenic mice in which $\alpha_{1 \mathrm{~A}}$ channels are ablated provide a powerful tool with which to test compensatory mechanisms at the synapse and to explore mechanisms of presynaptic regulation associated with expression of $P / Q$ channels. Using the calyx of Held preparation from the knock-out (KO) mice, we show here that $\mathrm{N}$-type channels functionally compensate for the absence of $\mathrm{P} / \mathrm{Q}$ subunits at the calyx and evoke giant synaptic currents [approximately two-thirds of the magnitude of wild-type (WT) responses]. However, although evoked paired-pulse facilitation is prominent in WT, this facilitation is greatly diminished in the KO. In addition, direct recording of presynaptic calcium currents revealed that the major functional difference was the absence of calcium-dependent facilitation at the calyx in the $\mathrm{P} / \mathrm{Q} \mathrm{KO}$ animals. We conclude that one physiological function of $\mathrm{P} / \mathrm{Q}$ channels is to provide additional facilitatory drive, so contributing to maintenance of transmission as vesicles are depleted during high throughput synaptic transmission.
\end{abstract}

Key words: synaptic transmission; knock-out mice; calyx of Held; calcium currents; $\mathrm{P} / \mathrm{Q}$ channels; facilitation

\section{Introduction}

Voltage-gated $\mathrm{Ca}^{2+}$ channels play a crucial role in neurotransmitter release at central and peripheral synapses, where exocytosis is frequently mediated by $\mathrm{P} / \mathrm{Q}-$ type $\mathrm{Ca}^{2+}$ channels (Katz et al., 1997; Iwasaki et al., 2000). Genetic ablation [knock-out (KO)] of the $\mathrm{Ca}_{\mathrm{v}} 2.1\left(\alpha_{1 \mathrm{~A}}\right)$ pore-forming subunit of the P/Q-type $\mathrm{Ca}^{2+}$ channel in mice induces a progressive neurological syndrome characterized by ataxia and early death at approximately postnatal day 20. Recent studies of transmission at the neuromuscular junction (NMJ) in these mice showed that $\mathrm{N}$ - and R-type $\mathrm{Ca}^{2+}$ channels replaced the deleted presynaptic P/Q-type channels so that the synapse then exhibited lower quantal output and an absence of paired-pulse facilitation (Urbano et al., 2003). Because of the inaccessibility of the presynaptic nerve terminal at the NMJ, we have refocused our studies on the calyx of Held. This giant synapse forms in the medial nucleus of the trapezoid body (MNTB) and functions as a relay in the binaural auditory brainstem computing sound source localization. Each MNTB principal neuron receives a somatic input from a single presynaptic calyx, where like in the NMJ, P/Q $\mathrm{Ca}^{2+}$ channels also predomi-

Received May 31, 2004; revised Sept. 8, 2004; accepted 0ct. 3, 2004.

This work was supported by Wellcome Trust Grant 068941/Z/02/Z, Agencia Nacional de Promoción Científica y Tecnológica Grant 6220, and Universidad de Buenos Aires Ciencia y Téchnica Grant X171. We thank Drs. Brian Billups and Fernando Marengo for advice and Silvina Estevez for technical help.

Correspondence should be addressed to Dr. 0. D. Uchitel, Instituto de Fisiología, Biología Molecular y Neurociencias, Universidad de Buenos Aires, Pabellon II, Piso 2, Ciudad Universitaria, Capital Federal, Buenos Aires 1428, Argentina. E-mail: odu@fbmc.fcen.uba.ar.

DOI:10.1523/JNEUROSCI.2104-04.2004

Copyright $\odot 2004$ Society for Neuroscience $\quad$ 0270-6474/04/2410379-05\$15.00/0 nantly trigger neurotransmitter release (Forsythe et al., 1998; Iwasaki and Takahashi, 1998). Our aim therefore is twofold: first to determine which channel subtypes compensate for P/Q channels at a central synapse and then to consider how mechanisms of facilitation are altered by this substitution.

Facilitation is an activity-dependent form of synaptic enhancement, which has been observed at invertebrate and vertebrate PNS and CNS synapses (for review, see Zucker and Regehr, 2002). Several models have been proposed to account for shortterm facilitation, including summation of residual calcium with repetitive stimulation (Katz and Miledi, 1968; Felmy et al., 2003), local saturation of calcium buffers (Blatow et al., 2003), and an independent facilitating $\mathrm{Ca}^{2+}$ sensor (Tsujimoto et al., 2002). One of the downstream effects of residual $\mathrm{Ca}^{2+}$ is the facilitation of $\mathrm{Ca}^{2+}$ currents. Facilitation by brief depolarizations has been reported at the calyx of Held (Borst and Sakmann, 1998; Cuttle et al., 1998; Forsythe et al., 1998), which despite its modest magnitude is of physiological relevance, because of the supralinear dependence of transmitter release on $\mathrm{Ca}^{2+}$ influx.

To determine how different types of presynaptic $\mathrm{Ca}^{2+}$ channels influence synaptic transmission and plasticity, we have made direct presynaptic recordings from the calyx of Held and from EPSCs in the soma of the MNTB neurons and compared results obtained from wild-type (WT) and $\mathrm{KO}$ mice.

Our results demonstrate that $\mathrm{P} / \mathrm{Q}$-type channels are replaced by $\mathrm{N}$-type channels in the calyx of Held of the mutant mice. However, whereas presynaptic $\mathrm{Ca}^{2+}$ currents $\left(I_{\mathrm{Ca}}\right)$ and evoked transmitter release facilitate with short-interval paired pulses in 
WT, paired-pulse facilitation of $I_{\mathrm{Ca}}$ and evoked transmitter release is greatly diminished in the $\mathrm{KO}$, emphasizing the importance of presynaptic calcium current activation in short-term synaptic plasticity.

\section{Materials and Methods}

Preparation of brainstem slices. Mice of 11-15 d of age were killed by decapitation, and their brains were removed rapidly and placed into an ice-cold low-sodium artificial CSF (aCSF). The brainstem was mounted in the Peltier chamber of an Integraslice 7550PSDS (Campden Instruments, Loughborough, UK) vibrating microslicer. Transverse slices containing MNTB were cut sequentially and transferred to an incubation chamber containing normal aCSF with low calcium $(0.1 \mathrm{~mm} \mathrm{CaCl}$ and $2.9 \mathrm{~mm} \mathrm{MgCl}_{2}$ ) at $37^{\circ} \mathrm{C}$ for $1 \mathrm{hr}$. After incubation, the chamber was allowed to return to room temperature. Slices of 150-200 $\mu \mathrm{m}$ thickness were used for presynaptic $\mathrm{Ca}^{2+}$ current recordings, and 300- $\mu \mathrm{m}$-thick slices were used for EPSC recordings. Normal aCSF contained (in mM): $125 \mathrm{NaCl}, 2.5 \mathrm{KCl}, 26 \mathrm{NaHCO}_{3}, 1.25 \mathrm{NaH}_{2} \mathrm{PO}_{4}, 10$ glucose, 0.5 ascorbic acid, 3 myo-inositol, 2 sodium pyruvate, $1 \mathrm{MgCl}_{2}$, and $2 \mathrm{CaCl}_{2}$. Lowsodium aCSF was as above, but $\mathrm{NaCl}$ was replaced by $250 \mathrm{~mm}$ sucrose, and $\mathrm{MgCl}_{2}$ and $\mathrm{CaCl}_{2}$ concentrations were 2.9 and $0.1 \mathrm{~mm}$, respectively. The $\mathrm{pH}$ was 7.4 when gassed with $95 \% \mathrm{O}_{2}$ and $5 \% \mathrm{CO}_{2}$.

Electrophysiology. Slices were transferred to an experimental chamber that was perfused with normal aCSF at $25^{\circ} \mathrm{C}$. MNTB neurons were visualized using Nomarski optics on a BX50WI (Olympus, Tokyo, Japan) microscope. Whole-cell voltage clamp recordings were made with patch pipettes pulled from thin-walled borosilicate glass (GC150F-15; Harvard Apparatus, Holliston, MA). Electrodes had resistances of 3.5-4.5 $\mathrm{M} \Omega$ when filled with internal solution. Patch pipette solutions contained (in mM): $110 \mathrm{CsCl}, 40$ HEPES, 10 TEA-Cl, 12 phosphocreatine, 0.5-2 EGTA, $2 \mathrm{MgATP}, 0.5 \mathrm{LiGTP}$, and $1 \mathrm{MgCl}_{2}$. The $\mathrm{pH}$ was adjusted to 7.3 with $\mathrm{CsOH}$. Lucifer yellow was included for visualizing presynaptic terminals. Patch-clamp recordings were made using an Axopatch 200B (Axon Instruments, Union City, CA) amplifier, a Digidata 1200 (Axon Instruments), and pClamp 8.1 software (Axon Instruments). Data were sampled at $5-20 \mathrm{kHz}$ and filtered at $4-6 \mathrm{kHz}$ (low-pass bessel). Series resistances ranged from 10 to $20 \mathrm{M} \Omega$ and were compensated by $50-60 \%$. Whole-cell membrane capacitance $(15-40 \mathrm{pF})$ was noted from the amplifier after compensation of the transient generated by a $10 \mathrm{msec}$ voltage step. $\mathrm{Ca}^{2+}$ currents were recorded in the presence of $1 \mu \mathrm{M}$ TTX and 10 mM TEA-Cl. Activation curves were obtained from tail currents recorded at the holding potential after depolarizing pulses and were fitted by a Boltzmann's function of the form: $I(V)=I_{\max } /\left(1+\exp \left(V_{1 / 2}-V\right) / k\right)$. EPSCs were recorded after addition of strychnine ( $10 \mu \mathrm{M}, \mathrm{aCSF})$ to block inhibitory glycinergic synaptic inputs and QX314 (10 mM) in the patch pipette solution to block $\mathrm{Na}^{+}$currents. Calyx of Held EPSCs were evoked by stimulating the globular bushy cell axons in the trapezoid body at the midline using a bipolar platinum stimulating electrode and an isolated stimulator. Stimuli of $0.1 \mathrm{msec}$ duration were applied every $10-30 \mathrm{sec}$.

Average data are expressed and plotted as mean \pm SEM. Statistical significance was determined using Student's $t$ test.

\section{Results}

Evoked EPSCs show reduced amplitude in $\mathrm{KO}$ mice

Calyx of Held synaptic responses were evoked in both WT and KO mice, showed synchronous release, and displayed all or nothing behavior and an amplitude (when above threshold) independent of stimulus intensity. Figure $1 A$ shows EPSCs recorded from the soma of an MNTB neuron under voltage-clamp conditions at a holding potential of $-70 \mathrm{mV}$. The mean EPSC amplitude was $5.8 \pm 0.6 \mathrm{nA}(n=7)$ in WT and $3.9 \pm 0.4 \mathrm{nA}(n=7)$ in KO. This suggests a reduction of synaptic current magnitude of $32.6 \%$ in the KO compared with WT mice, whereas the mean $10-90 \%$ rise time showed no significant difference: $0.28 \pm 0.02 \mathrm{msec}$ for WT and $0.34 \pm 0.03 \mathrm{msec}$ for $\mathrm{KO}(n=7)$. The EPSC decay time was fit by a double exponential function with similar fast $\left(\tau_{1}\right)$ and
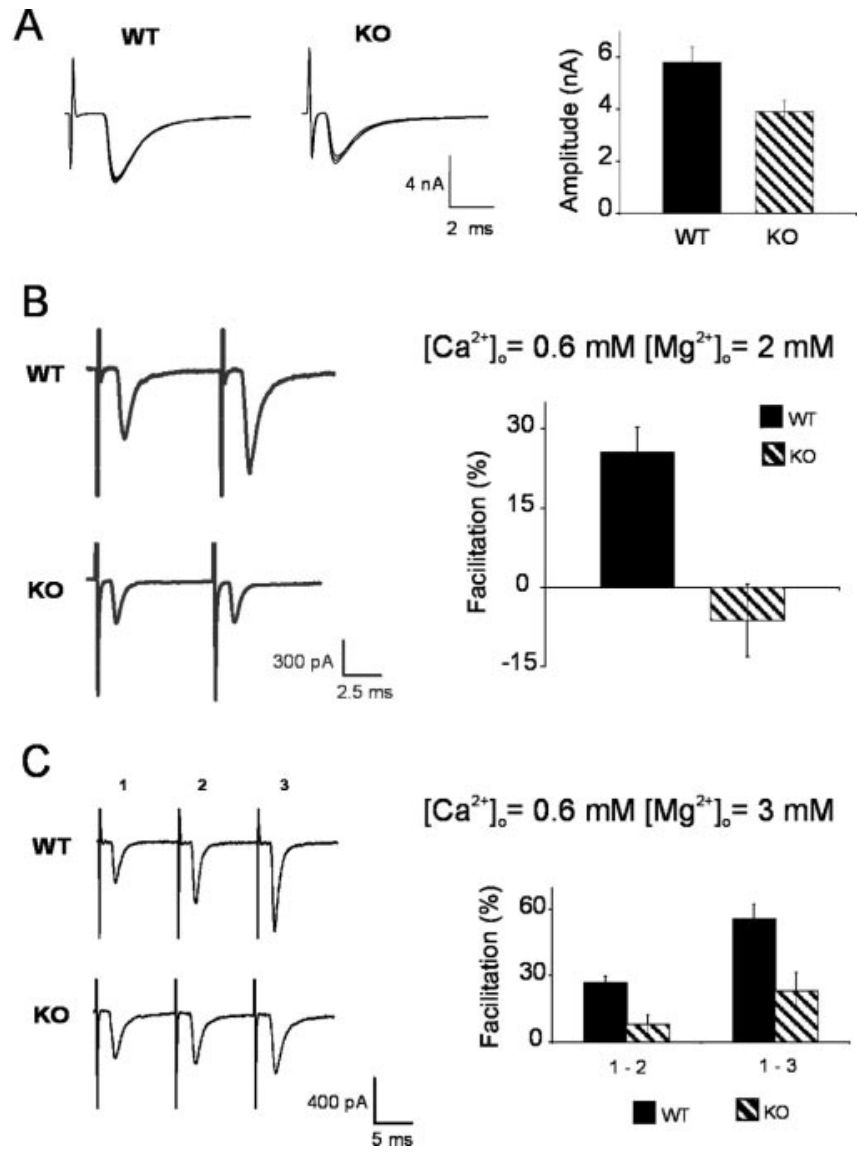

$\left[\mathrm{Ca}^{2+}\right]_{0}=0.6 \mathrm{mM}\left[\mathrm{Mg}^{2+}\right]_{0}=3 \mathrm{mM}$

Figure 1. P/Q KO mice have reduced evoked postsynaptic current (EPSC) and greatly diminished paired-pulse facilitation. EPSCs were evoked in MNTB neurons by stimulation with a bipolar electrode placed at the midline of the brainstem slice. A, Stimuli of 0.1 msec duration and 3-10 V amplitude were applied every $10-30 \mathrm{sec}$. Currents were recorded under whole-cell voltage-clamp conditions at a holding potential of $-70 \mathrm{mV}$. The EPSC mean amplitude is $5.8 \pm$ $0.6 \mathrm{nA}(n=7)$ for WT and $3.9 \pm 0.4 \mathrm{nA}(n=7)$ for the K0, giving a $33 \%$ reduction in the synaptic current from KO mice with respect to WT. Differences in the $10-90 \%$ rise time and decaying time constants are not statistically significant (see Results). $B$, A pair of stimuli (as in $A$ ) was applied with a short interval $(10 \mathrm{msec})$. Left, In low external $\mathrm{Ca}^{2+}$ concentration $(0.6 \mathrm{~mm})$ and high external $\mathrm{Mg}^{2+}$ concentration ( $2 \mathrm{mM}$ ), the WT EPSC evoked by the second stimulus is facilitated with respect to the first EPSC. In contrast, no facilitation is observed in $\mathrm{KO}$ cells. Right, Mean magnitude of facilitation is $25 \pm 5 \%(n=5)$ for WT and $-6.2 \pm 6.8 \%(n=6)$ for the KO. C, When the release probability is further attenuated by increasing the external $\mathrm{Mg}^{2+}$ concentration to $3 \mathrm{~mm}$, a small facilitation can be measured in $\mathrm{KO}$ mice. Left, Sample recordings of EPSCs from WT and KO mice. Right, Mean magnitude of facilitation between the second and first pulse is $26.9 \pm 4 \%$ in WT mice $(n=3)$ and $7.8 \pm 4.3 \%$ in KO $(n=3)$. Between the third and first pulse, the magnitude of facilitation is $55 \pm 7 \%$ for WT and $23 \pm 9 \%$ for KO.

slow $\left(\tau_{2}\right)$ time constants (and relative amplitudes) in control and transgenic mice: for WT, $\tau_{1}=0.91 \pm 0.09 \mathrm{msec}(23.5 \pm 0.6 \%)$, $\tau_{2}=5.5 \pm 0.4 \mathrm{msec}(76.5 \pm 0.5 \%)$; and for $\mathrm{KO}, \tau_{1}=0.69 \pm 0.07$ $\operatorname{msec}(23.2 \pm 1.2 \%), \tau_{2}=6.5 \pm 0.6 \mathrm{msec}(76.8 \pm 1.2 \%)$. The similar time course suggests that loss of $\mathrm{P} / \mathrm{Q}$-type channels does not profoundly change the expression of postsynaptic glutamate receptors.

\section{Paired-pulse facilitation of EPSCs is greatly diminished in KO mice}

Paired-pulse facilitation is a form of short-term synaptic plasticity evoked using a double pulse protocol; suprathreshold stimuli were applied to the trapezoid axons with a short interstimulus interval (10 msec) and the postsynaptic responses recorded under voltage clamp. In normal aCSF $\left(2 \mathrm{mM} \mathrm{Ca}^{2+}\right.$ and $1 \mathrm{~mm}$ 
$\mathrm{Mg}^{2+}$ ), the release probability and hence EPSC magnitude were too large, and the dominant feature of the second EPSC was depression (Wong et al., 2003). These studies were therefore conducted in aCSF containing low $\mathrm{Ca}^{2+}(0.6 \mathrm{~mm})$ and high $\mathrm{Mg}^{2+}(2$ $\mathrm{mM}$ ), in which the paired EPSC was clearly facilitated in the WT mouse with respect to the first conditioning evoked response $(25 \pm 5 \% ; n=5)$. After increasing the interstimulus interval, the EPSC facilitation decayed with a time constant of $19.3 \pm 5.6 \mathrm{msec}$ $(n=6)$. Under the same conditions, EPSCs in KO mice showed no facilitation: $-6.2 \pm 6.8 \%,(n=6)$ (Fig. $1 B)$. Because the degree of facilitation increases as release probability is reduced, lowering release probability still further (by increasing extracellular $\mathrm{Mg}^{2+}$ to $3 \mathrm{mM}$ ) unmasked a small facilitation of $7.8 \pm 4.3 \%$ $(n=3)$ in the KO compared with a much greater response of $27 \pm 4 \%(n=2)$ in WT (Fig. $1 C)$, indicating that increases in transmitter release are nevertheless possible in the $\mathrm{KO}$ animal.

\section{Presynaptic $\mathrm{Ca}^{2+}$ currents characterization at the calyx of Held}

To learn more about the underlying mechanisms responsible for the differences in the KO calyx of Held-MNTB-evoked EPSC, the pharmacological and electrophysiological characteristics of presynaptic $I_{\mathrm{Ca}}$ were studied. Presynaptic $\mathrm{Ca}^{2+}$ currents were elicited by $30 \mathrm{msec}$ depolarizing pulses from a holding potential of -70 to $-10 \mathrm{mV}$ under whole-cell voltage-clamp conditions. Lucifer yellow was used to visually confirm the presynaptic recording.

\section{Current density and pharmacological characterization}

The average presynaptic $I_{\mathrm{Ca}}$ density was $39.4 \pm 2.5 \mathrm{pA} / \mathrm{pF}(n=$ $11)$ in WT and $26.0 \pm 3.2 \mathrm{pA} / \mathrm{pF}(n=7)$ in $\mathrm{KO}$ mice, so the $\mathrm{KO}$ has approximately one-third less voltage-gated divalent current than a WT terminal.

To identify which $\mathrm{Ca}^{2+}$ channel subtypes were involved, we made long-duration recordings of peak currents after sequential application of selective N,P/Q, L, and R-type $\mathrm{Ca}^{2+}$ channel antagonists: $\omega$-conotoxin GVIA $(2 \mu \mathrm{M})$, $\omega$-agatoxin IVA $(200 \mathrm{nM})$, nitrendipine $(10 \mu \mathrm{M})$, and nickel $(50 \mu \mathrm{M})$, respectively (Fig. $2 A)$. In $\mathrm{WT}$ there was a high contribution of $\mathrm{P} / \mathrm{Q} \mathrm{Ca}^{2+}$ channels, with $\omega$-agatoxin IVA blocking $80.8 \pm 2.4 \%$ of the $\mathrm{Ca}^{2+}$ currents and $11.5 \pm 1.6 \%$ of $\mathrm{N}$-type component $(n=4)$. Tissue from the $\mathrm{KO}$ animal showed no sensitivity to $\omega$-agatoxin IVA, indicating that $P / Q$ $\mathrm{Ca}^{2+}$ channels were absent, whereas the $\mathrm{N}$-type contribution was $92.7 \pm 1.3 \%$ (Fig. $2 B$ ) of the total divalent current $(n=4)$.

\section{Voltage dependence and activation kinetics}

To examine the current-voltage ( $I-V)$ relationship of the presynaptic calcium current, terminals were depolarized from a holding potential of $-70 \mathrm{mV}$ to potentials ranging from -60 to $+60 \mathrm{mV}$ ( $5 \mathrm{mV}$ increments, duration of $30 \mathrm{msec}$ ) (Fig. $3 A$ ). $\mathrm{Ca}^{2+}$ currents activated at approximately $-35 \mathrm{mV}$ and showed an apparent reversal potential of $\sim 45-50 \mathrm{mV}$. The peak inward current was at $-10 \mathrm{mV}$ for WT $(n=11)$ and at $-5 \mathrm{mV}$ in $\mathrm{KO}$ mice $(n=7)$. Current-voltage curves in Figure $3 B$ have been normalized to the peak current amplitude. When $\mathrm{P} / \mathrm{Q} \mathrm{Ca}^{2+}$ channels were blocked in WT mice using $\omega$-agatoxin IVA, the voltage dependence of the remaining calcium current was shifted to positive potentials as for the N-type currents measured in $\mathrm{KO}$ mice.

The same shift toward depolarized potentials in the $\mathrm{KO}$ with respect to $\mathrm{WT}$ is seen for activation curves measured from tail currents (Fig. $3 C$ ). Half-activation $\left(V_{1 / 2}\right)$ voltages in $\mathrm{KO}$ mice were $8 \mathrm{mV}$ more positive than in WT mice: $V_{1 / 2}=-14.98 \pm 0.06$ $\mathrm{mV}$ for $\mathrm{KO}(n=7)$ and $-23.3 \pm 0.3 \mathrm{mV}$ for WT $(n=11)$, but the
A
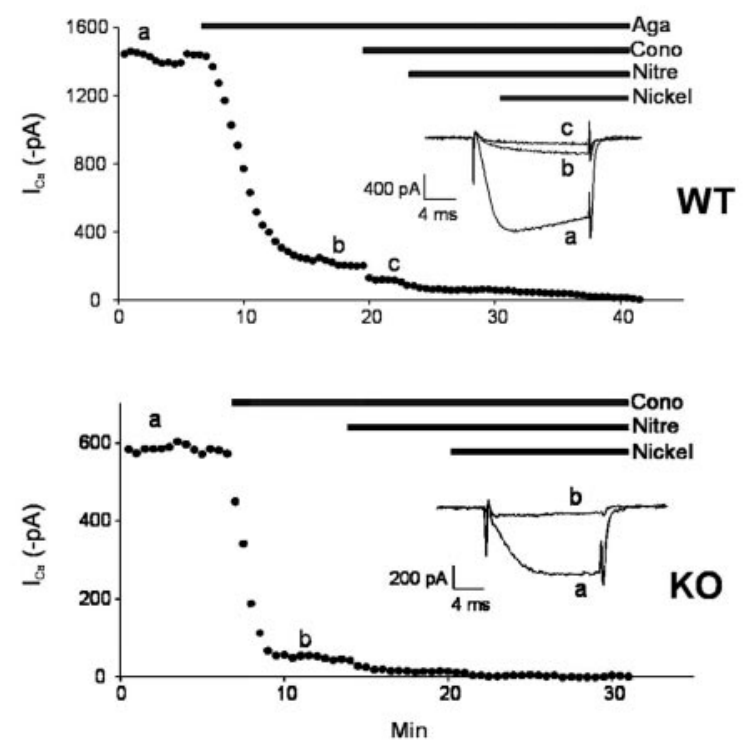

B
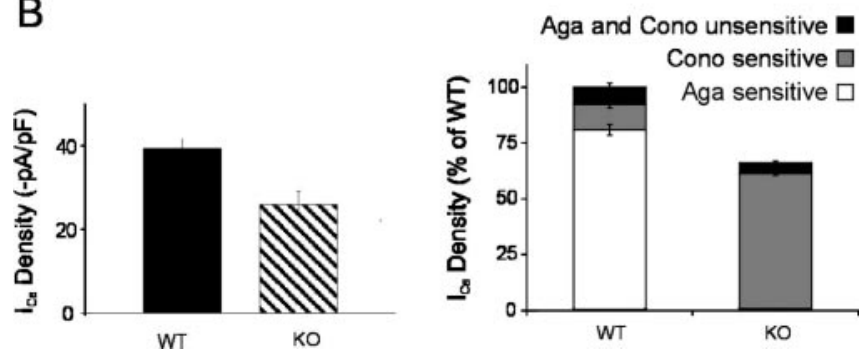

Figure 2. N-type channels replace $P / Q$-type channels at the calyx of Held presynaptic nerve terminal. Pharmacological dissection of whole-cell presynaptic $\mathrm{Ca}^{2+}$ current subtypes. Calcium currents were evoked by $30 \mathrm{msec}$ step depolarization to $-10 \mathrm{mV}$ from a holding potential of $-70 \mathrm{mV}$. A, A plot of calcium current amplitude against time (top, WT; bottom, K0), illustrating the time course of current block by sequential application of selective $\mathrm{N}, \mathrm{P} / \mathrm{Q}, \mathrm{L}$, and $\mathrm{R} \mathrm{Ca}^{2+}$ channel antagonists: $\omega$-conotoxin-GVIA (Cono; $2 \mu \mathrm{M}), \omega$-agatoxin IVA (Aga; $200 \mathrm{~nm})$, nitrendipine (Nitre; $10 \mu \mathrm{M}$ ), and nickel $(50 \mu \mathrm{M})$, respectively. Horizontal bars indicate the time of drug application. Inset, Representative curve traces during the step to $-10 \mathrm{mV}$ elicited at the time points indicated by lowercase letters. The lack of effect of $\omega$-agatoxin IVA on KO mice presynaptic $\mathrm{Ca}^{2+}$ currents was demonstrated in other experiments. $B$, Left, Average presynaptic $I_{\mathrm{Ca}}$ density is $39.4 \pm 2.5 \mathrm{pA} / \mathrm{pF}(n=11)$ in $\mathrm{WT}$ and $26.0 \pm 3.2 \mathrm{pA} / \mathrm{pF}(n=7)$ in $\mathrm{KO} ; p=0.0022$. Right, Fractional contribution of each channel type to the total calcium current determined by subtracting current amplitudes before and after application of specific blockers. The P/Q component was $80.8 \pm 2.4 \%(n=4)$ in WT mice, whereas in KO mice, this channel was absent. The $\mathrm{N}$-type component was $11.5 \pm 1.6 \%(n=4)$ in WT mice and $92.7 \pm 1.3 \%(n=4)$ in K0 mice.

slope factors were similar: $k=5.87 \pm 0.06$ and $5.17 \pm 0.26 \mathrm{mV}$, respectively.

Presynaptic $\mathrm{Ca}^{2+}$ currents undergo facilitation in WT and depression in $\mathrm{KO}$

It has been reported that presynaptic calcium currents at the calyx of Held display $\mathrm{Ca}^{2+}$-dependent facilitation (Borst et al., 1998; Cuttle et al., 1998; Forsythe et al., 1998). Considering the reduced EPSC facilitation observed in the $\mathrm{KO}$, this could result from an altered sensitivity during facilitating stimuli. To examine this possibility, pairs of brief depolarizing pulses ( $2 \mathrm{msec}$ from -70 to $-10 \mathrm{mV}$ ) were applied at short interpulse intervals (5-50 msec) to the presynaptic calyx of Held. In measurements from WT mice, the second current showed clear facilitation with respect to the first; with maximum facilitation (measured with a 5-10 msec interval) decreasing with longer interpulse intervals with a time constant of $16.9 \pm 5.1 \mathrm{msec}(n=6)$ (Fig. $4 A, C)$. At $2 \mathrm{~mm}$ extracellular $\mathrm{Ca}^{2+}$ and 2 mM EGTA in the internal solution, the second 
A

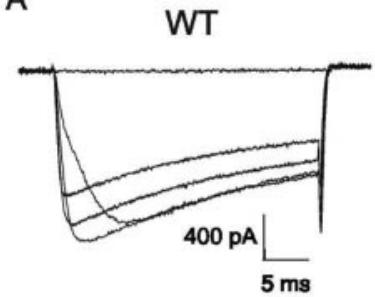

B

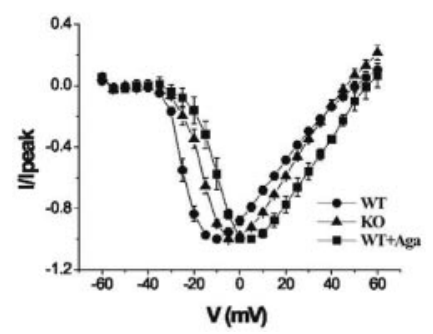

C

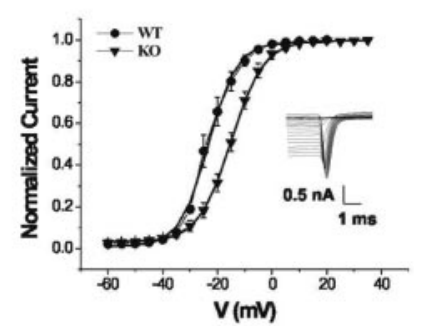

Figure 3. Positive shift of presynaptic $\mathrm{Ca}^{2+}$ current activation in $\mathrm{KO}$ and for presynaptic $\mathrm{N}$-type currents in WT mice. $A$, Sample traces of presynaptic $\mathrm{I}_{\mathrm{Ca}}$ evoked by 30 msec depolarizing pulses between -60 and $60 \mathrm{mV}(5 \mathrm{mV}$ steps) from a holding potential of $-70 \mathrm{mV}$. Left, WT; right, KO. B, Current-voltage relationship from WT, KO, and WT presynaptic terminals after application of $200 \mathrm{~nm} \omega$-agatoxin-IVA (Aga). C, I Ca $_{\text {a }}$ activation curves: tail currents are normalized to the maximum peak amplitude, plotted against voltage, and fitted by a Boltzmann's distribution function. The half-activation voltage in $\mathrm{KO}$ mice $(-14.98 \pm 0.06 \mathrm{mV} ; n=7)$ is $8 \mathrm{mV}$ more positive than that in WT mice $(-23.3 \pm 0.3 \mathrm{mV} ; n=11)$. Slope factors are similar: $5.87 \pm 0.06 \mathrm{mV}$ for WT and $5.17 \pm 0.26 \mathrm{mV}$ for K0. Inset, Sample traces of tail current elicited by repolarization of the presynaptic terminal to the holding potential of $-70 \mathrm{mV}$ from the different depolarizing potentials specified above.
A

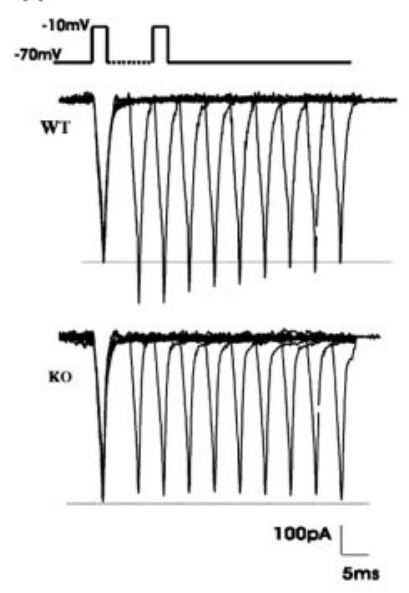

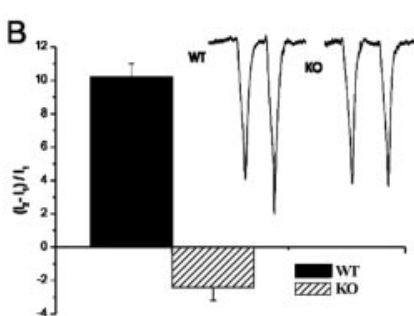

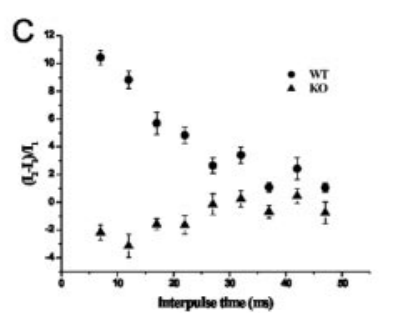

Figure 4. Presynaptic $\mathrm{Ca}^{2+}$ current facilitation is absent in $\mathrm{KO}$ nerve terminals. $\mathrm{Ca}^{2+}$ currents were generated by a pair of $2 \mathrm{msec}$ depolarizing to $-10 \mathrm{mV}$ from a holding potential of $-70 \mathrm{mV}$, with different interpulse time intervals between 5 and $45 \mathrm{msec}$. A, Paired-pulse voltage protocol (broken line indicates that time between pulses is variable between 5 and 45 $\mathrm{msec}$ ) and sample traces (superimposed for all interpulse intervals) showing facilitation in WT and a small depression in KO. $B$, Mean percentage of facilitation at a 5 msec interpulse interval: $10.2 \pm 0.8 \%(n=14)$ for WT and $-2.4 \pm 0.8 \%(n=9)$ for K0. Inset, Paired-pulse sample traces. C, Dependence of paired-pulse facilitation with the time interval between pulses, for WT and $\mathrm{KO}$.

$I_{\mathrm{Ca}}$ showed $10.2 \pm 0.8 \%$ facilitation $(n=14)$. In contrast, $I_{\mathrm{Ca}}$ from $\mathrm{KO}$ mice showed a mean depression of $-2.4 \pm 1 \%$ under the same conditions $(n=9)$ (Fig. 4A,B). The dependence of the mean magnitude of facilitation with the interpulse time interval is plotted in Figure 4C.

\section{Discussion}

These results clearly show that, after deletion of the $\alpha_{1 \mathrm{~A}}$ subunit, $\mathrm{P} / \mathrm{Q}$-type calcium channels are replaced predominantly by $\mathrm{N}$-type channels at the calyx of Held presynaptic terminal. This compensation results in functional synaptic transmission but altered short-term plasticity mediated by calcium-dependent modulation of the presynaptic channels. These data suggest that one special physiological role of $\mathrm{P} / \mathrm{Q}$-type channels over $\mathrm{N}$-type channels is to provide a short-term facilitatory mechanism at fast-transmitting synapses.

In newborn WT mice, N-type channels are normally expressed at presynaptic nerve terminals, but their contribution decreases during development, being replaced by P/Q-type channels at approximately the age when functional hearing starts (on opening of the auditory canal, postnatal day 11). The fact that $\mathrm{N}$-type channels compensate for the lack of P/Q channels is interesting, because R-type channels mediate transmitter release at fast synapses (Brenowitz and Regehr, 2003), are present at the calyx during development (Wu et al., 1998), and are known to participate in transmission. The more positive activation voltage of $\mathrm{N}$-type $\mathrm{Ca}^{2+}$ currents (half-activation $8 \mathrm{mV}$ more depolarized) seems a distinctive property of $\mathrm{N}$-type channels compared with P/Q channels (Ishikawa et al., 2003). The same shift was observed in the N-type currents in the calyx of WT mice after incubation with the P/Q-type channel blocker (Fig. 3) (Currie and Fox, 1997). Differences in the activation kinetics could result from the expression of different $\alpha$ subunit isoforms or different auxiliary subunits.

The fact that P/Q-type currents activate at more negative potentials supports the idea that more $\mathrm{Ca}^{2+}$ will flow into the terminal during an action potential in the $\mathrm{WT}$, resulting in more efficient synaptic transmission. Influx of $\mathrm{Ca}^{2+}$ into the calyx via $\mathrm{N}$-type channels in the early stages of development triggers neurotransmitter release less effectively than via $\mathrm{P} / \mathrm{Q}$ channels because of their more distant localization from the release sites $(\mathrm{Wu}$ et al., 1999). This could be a general phenomenon, because $\mathrm{N}$-type replacement of the P/Q-channels at the $\alpha_{1 \mathrm{~A}} \mathrm{KO}$ neuromuscular junction is also located more distantly from the release site (Urbano et al., 2003).

Two groups have independently reported presynaptic calcium current facilitation elicited by brief paired depolarizations with short intervals at the calyx of Held (Borst et al., 1998; Cuttle et al., 1998). This activity-dependent facilitation of $\mathrm{Ca}^{2+}$ currents results from a $\mathrm{Ca}^{2+}$-dependent increase in activation kinetics (Cuttle et al., 1998). In the present work, paired-pulse facilitation was present in the WT but not in the KO mice. In every single KO experiment, calcium currents failed to show facilitation, independently of the control current magnitude. In contrast, calcium currents from WT mice displayed a clear facilitation in the amplitude of the second current. These results suggest that the lack of facilitation is a particular feature of N-type currents in the presynaptic nerve terminal and is not caused by the reduced current magnitude. The fact that neither P/Q-type nor N-type currents in WT mice MNTB display paired-pulse facilitation of postsynaptic somatic $\mathrm{Ca}^{2+}$ currents (our unpublished observation) suggests that presynaptic facilitation depends on the expression of particular $\mathrm{Ca}^{2+}$ channel isoforms combined with local interactions with other molecules, such as NCS-1 Ca ${ }^{2+}$-binding proteins (Tsujimoto et al., 2002).

In normal $\mathrm{Ca}-\mathrm{Mg}$ concentrations, high-frequency stimulation triggers EPSCs that may facilitate (Wong et al., 2003) but then exhibit profound depression at the same rate in the WT and 
KO mice. This depression is caused by the combined effects of vesicle depletion and postsynaptic AMPA receptor desensitization (Schneggenburger et al., 2002; Wong et al., 2003). When quantal output was reduced in our experiments, WT EPSCs displayed a strong facilitation, whereas KO EPSCs showed depression or significantly smaller facilitation.

Facilitation of transmitter release has been mainly attributed to residual $\mathrm{Ca}^{2+}$ (Katz and Miledi, 1968; Zucker and Regehr, 2002). In invertebrates and lizard synapses, the contribution of presynaptic currents to this phenomenon was not supported by experimental evidence (Charlton et al., 1982; David et al., 1997). However, at the calyx of Held, presynaptic $\mathrm{Ca}^{2+}$ currents facilitate and may contribute to short-term facilitation of transmitter release (Borst et al., 1998; Cuttle et al., 1998). Considering the nonlinear power relationship between transmitter release and presynaptic calcium current, the lack of a $10-15 \%$ facilitation of the KO presynaptic calcium current may fully explain the reduced facilitation of transmitter release observed under our recording conditions. This interpretation is supported by the similar decay time course of both types of facilitation. However, the lack of information on $\mathrm{Ca}^{2+}$ concentration at the vesicle release site, the degree of vesicle depletion, and the degree of postsynaptic glutamate receptor desensitization after the first pulse preclude more definitive calculation. Further reduction of the release probability at the KO MNTB synapse unmasked EPSC facilitation, indicating that other factors may also contribute. In fact, a large calcium current-independent component of synaptic facilitation has been recently postulated (Felmy et al., 2003).

The fact that the KO calyx EPSC facilitation as well as presynaptic calcium current facilitation are both diminished demonstrates a clear role of activity-dependent calcium current facilitation in the generation of this short-term synaptic plasticity in this giant synapse. This interpretation might be extended to other synapses, such as the NMJ, where in normal animals the P/Q channel almost exclusively mediates transmitter release and where the $\mathrm{KO}$ animal also lacks paired-pulse facilitation (Urbano et al., 2003). In contrast, facilitation persists in hippocampal CA1 synapses (R. Pisnoy and O. D. Uchitel, unpublished observations) and in granular-Purkinje cell synapses of the $\mathrm{KO}$ animal (Miyazaki et al., 2004). This difference could be related to the fact that at these synapses, transmitter release normally depends on more than one type of $\mathrm{Ca}^{2+}$ channel (Wu and Saggau, 1994; Sabatini and Regehr, 1997).

\section{References}

Blatow M, Caputi A, Burnashev N, Monyer H, Rozov A (2003) $\mathrm{Ca}^{2+}$ buffer saturation underlies paired pulse facilitation in calbindin-D28kcontaining terminals. Neuron 38:79-88.

Borst JG, Sakmann B (1998) Facilitation of presynaptic calcium currents in the rat brainstem. J Physiol (Lond) 513:149-155.

Brenowitz SD, Regehr WG (2003) "Resistant" channels reluctantly reveal their roles. Neuron 39:391-394.

Charlton MP, Smith SJ, Zucker RS (1982) Role of presynaptic calcium ions and channels in synaptic facilitation and depression at the squid giant synapse. J Physiol (Lond) 323:173-193.

Currie KP, Fox AP (1997) Comparison of N- and P/Q-type voltage-gated calcium channel current inhibition. J Neurosci 17:4570-4579.

Cuttle MF, Tsujimoto T, Forsythe ID, Takahashi T (1998) Facilitation of the presynaptic calcium current at an auditory synapse in rat brainstem. J Physiol (Lond) 512:723-729.

David G, Barrett JN, Barrett EF (1997) Stimulation-induced changes in $\left[\mathrm{Ca}^{2+}\right]$ in lizard motor nerve terminals. J Physiol (Lond) 504:83-96.

Felmy F, Neher E, Schneggenburger R (2003) Probing the intracellular calcium sensitivity of transmitter release during synaptic facilitation. Neuron 37:801-811.

Forsythe ID, Tsujimoto T, Barnes-Davies M, Cuttle MF, Takahashi T (1998) Inactivation of presynaptic calcium current contributes to synaptic depression at a fast central synapse. Neuron 20:797-807.

Ishikawa T, Hee-Sup S, Takahashi T (2003) Distinct and common properties of N-type and P/Q-type calcium currents at the calyx of Held presynaptic terminal. J Physiol (Lond) 551P:C28.

Iwasaki S, Takahashi T (1998) Developmental changes in calcium channel types mediating synaptic transmission in rat auditory brainstem. J Physiol (Lond) 509:419-423.

Iwasaki S, Momiyama A, Uchitel OD, Takahashi T (2000) Developmental changes in calcium channel types mediating central synaptic transmission. J Neurosci 20:59-65.

Katz B, Miledi R (1968) The role of calcium in neuromuscular facilitation. J Physiol (Lond) 195:481-492.

Katz E, Protti DA, Ferro PA, Rosato Siri MD, Uchitel OD (1997) Effects of $\mathrm{Ca}^{2+}$ channel blocker neurotoxins on transmitter release and presynaptic currents at the mouse neuromuscular junction. Br J Pharmacol 121:15311540.

Miyazaki T, Hashimoto K, Shin HS, Kano M, Watanabe M (2004) P/Q-type $\mathrm{Ca}^{2+}$ channel $\alpha 1 \mathrm{~A}$ regulates synaptic competition on developing cerebellar Purkinje cells. J Neurosci 24:1734-1743.

Sabatini BL, Regehr WG (1997) Control of neurotransmitter release by presynaptic waveform at the granule cell to Purkinje cell synapse. J Neurosci 17:3425-3435.

Schneggenburger R, Sakaba T, Neher E (2002) Vesicle pools and short-term synaptic depression: lessons from a large synapse. Trends Neurosci $25: 206-212$.

Tsujimoto T, Jeromin A, Saitoh N, Roder JC, Takahashi T (2002) Neuronal calcium sensor 1 and activity-dependent facilitation of P/Q-type calcium currents at presynaptic nerve terminals. Science 295:2276-2279.

Urbano FJ, Piedras-Renteria ES, Jun K, Shin HS, Uchitel OD, Tsien RW (2003) Altered properties of quantal neurotransmitter release at endplates of mice lacking P/Q-type $\mathrm{Ca}^{2+}$ channels. Proc Natl Acad Sci USA 100:3491-3496.

Wong AY, Graham BP, Billups B, Forsythe ID (2003) Distinguishing between presynaptic and postsynaptic mechanisms of short-term depression during action potential trains. J Neurosci 23:4868-4877.

Wu LG, Saggau P (1994) Pharmacological identification of two types of presynaptic voltage-dependent calcium channels at CA3-CA1 synapses of the hippocampus. J Neurosci 14:5613-5622.

Wu LG, Borst JG, Sakmann B (1998) R-type Ca ${ }^{2+}$ currents evoke transmitter release at a rat central synapse. Proc Natl Acad Sci USA 95:4720-4725.

Wu LG, Westenbroek RE, Borst JG, Catterall WA, Sakmann B (1999) Calcium channel types with distinct presynaptic localization couple differentially to transmitter release in single calyx-type synapses. J Neurosci 19:726-736.

Zucker RS, Regehr WG (2002) Short-term synaptic plasticity. Annu Rev Physiol 64:355-405. 